\title{
The Differences in the Usage of Social Media between SMEs operating in the Iron and Mining Industries
}

\author{
Aleksandr KLJUČNIKOV ${ }^{1}$, Mehmet CIVELEK ${ }^{* 2}$, Vladimír VAVREČKA ${ }^{3}$ \\ and Václav NÉTEK ${ }^{4}$
}

Authors' affiliations and addresses:

${ }^{1}$ Institute of Entrepreneurship and Marketing,

University of Entrepreneurship and Law,

Michálkovická 1810/181, 71000 Ostrava-Slezská

Ostrava, Czech Republic

e-mail: kliuchnikov@gmail.com

${ }^{2}$ Institute of Entrepreneurship and Marketing,

University of Entrepreneurship and Law,

Michálkovická 1810/181, 71000 Ostrava-Slezská

Ostrava, Czech Republic

e-mail: $\underline{m}$ civelek@windowslive.com

${ }^{3}$ Institute of Entrepreneurship and Marketing,

University of Entrepreneurship and Law,

Michálkovická 1810/181, 71000 Ostrava-Slezská

Ostrava, Czech Republic

e-mail: vavreckav@vspp.cz

${ }^{4}$ Institute of Entrepreneurship and Marketing,

University of Entrepreneurship and Law,

Michálkovická 1810/181, 71000 Ostrava-Slezská

Ostrava, Czech Republic

e-mail: vaclav.netek@vspp.cz

*Correspondence:

Mehmet Civelek, Institute of Entrepreneurship and Marketing, University of Entrepreneurship and Law, Michálkovická 1810/181, 71000 Ostrava-Slezská Ostrava, Czech Republic tel.: +420773873403

e-mail: $\underline{\text { m_civelek@windowslive.com }}$

Funding information:

Funding Agency: VEGA

Grant Number: VEGA 1/0813/19

Acknowledgement: This research was supported by the project VEGA 1/0813/19 "Managing the development of innovative and start-up forms of businesses in international environment and verification of INMARK concept", which has received funding from the Ministry of Education, Science, Research and Sport of the Slovak Republic.

How to cite this article:

Ključnikov, A., Civelek, M., Vavrečka, V. and Nétek, V. (2021). The Differences in the Usage of Social Media between SMEs operating in the Iron and Mining Industries. Acta Montanistica

Slovaca. Volume 26 (2) 185-194

DOI:

https://doi.org/10.46544/AMS.v26i2.01

\begin{abstract}
Since Small and Medium-sized Enterprises (SMEs) in iron and mining industries are significant contributors not only for Gross Domestic Product (GDP) and labour creation of countries but also export volumes of nations, they have also crucial roles to reduce unemployment rates, and increase amount of exports. But comparing to their larger counterparts, SMEs encounter more financing obstacles that might make them to become noncompetitive. Within this context, their usage of social media platforms might increase their competitiveness because these digital marketing channels provide less costly solutions for their activities. But depending on their characteristics, their willingness and propensity to implement social media channels in their marketing operations can show differences. In this regard, this paper intends to examine whether the usage of social media channels by SMEs in iron and mining industries differ depending on their size and length of doing business. To hit this target, the researchers have created a questionnaire survey and have directed it to the randomly selected respondents from Cribis database. 702 SMEs that operate iron and mining industries of Slovakia and Hungary have fulfilled the survey. Independent Sample T test is applied to explore differences in the selected variables. While the usage of social media platforms by smaller and larger SMEs does not differ, older SMEs apply social media channels more than younger SMEs. These results are consistent for both Slovak and Hungarian SMEs. The reason of similarities in both nations' SMEs might be related with similar social-economic conditions of these nations, education level and experience of firm executives. The cooperation of policymakers with SMEs, universities, industrial zones, and unions to encourage the effective usage of social media channels might increase SMEs operating in mining and iron industries and their executives' competencies and competitive postures to contest with their largersized counterparts.
\end{abstract}

\section{Keywords}

social media, marketing, age, size, Slovakia, Hungary, SMEs, digital marketing, online marketing, length of doing business, iron and mining industries. 


\section{Introduction}

The existence of internet and the developments in the information technologies have increased digitalization processes of marketing activities by providing the usage of technology enabled marketing tools and internetbased applications for SMEs. In this regard, the usage of these channels by SMEs might provide advantages for SMEs when competing with their larger rivals. Since larger enterprises more assets and financial resources than SMEs, adoption and usage of social media networks that provide less costly marketing activities and widen networks might enable SMEs to close the gap between their larger rivals. In industries where the competition is fierce such as iron and mining industries, the usage of these platforms might be more beneficial for SMEs. This is because firms in those industries do not only present their products and services via those platforms but also they become aware of new trends and goods in their sectors. Hence, businesses try to differentiate themselves against their competitors by stimulating their innovative posture (Quinton \& Wilson, 2016; Freixanet et al., 2020) and SMEs in those industries stay competitive and get some clues from their competitors not only depending their locational advantages such as agglomeration. In this regard, the aim of this research is to analyse and investigate the differences between older-younger, smaller and larger SMEs operating in mining and iron industries regarding their usage of social media platforms. SMEs are categorized under three different segments depending on their size, namely micro, small and medium-sized. While the number of staff headcount for micro enterprises differ between 0 to 9 , small firms have employees between 10 to 49 , and medium sized enterprises employ workers around 50 to 249 (European Commission, 2003).

Social media tools can be defined as applications that are available with internet connection and provide their users to explore novel notions and share this information with videos, photos, and messages to other users via these channels (Wardati \& Mahendrawathi, 2019; Mount \& Martinez, 2014). In this regard, most of businesses become able to give information about their products and services (Hitchen et al., 2017; Freixanet et al., 2020). Except reducing marketing costs, the usage of social media also positively affects performance (Olanrewaju et al., 2020), competitiveness (Guha et al., 2018; Qalati et al., 2020), revenues (Shaltoni, 2017), sales (Wardati \& Mahendrawathi, 2019), profitability (Jokonya \& Mugisha, 2019) and marketing activities of firms (Jokonya \& Mugisha, 2019; Wardati \& Mahendrawathi, 2019). Enterprises might use social media networks to fulfil their different marketing targets such as branding (Jokonya \& Mugisha, 2019), promotion (Freixanet et al., 2020), customer relationship, advertising and reputation strategies (Wardati \& Mahendrawathi, 2019). Social media networks and applications also make businesses to deploy their human resources. Since these platforms reduce the talk times via telephone conversations, workers can be more canalized solving issues that they receive as feedbacks from these channels (Jokonya \& Mugisha, 2019).

Social media networks and platforms have many advantages for their prospective and existing users including businesses. In detail, these channels provide less costly transaction costs for marketing activities of enterprises (Stockdale, et al., 2012; Hitchen et al., 2017) and do not require superior skills to use it (Olanrewaju et al., 2020). Therefore, it is also a convenient option for enterprises to achieve both having easier contacts with their customers and suppliers and sharing information via social media networks (Jokonya \& Mugisha, 2019). Social media platforms increase visibility of enterprises and their interactions with their costumers and suppliers (Qalati et al., 2020). By receiving feedbacks from their customers, firms can also develop their products and services by applying innovative activities. These facts also make enterprises to be aware of their customers' demands and quickly find appropriate solutions to fulfil these demands (Wardati \& Mahendrawathi, 2019). To sum up, SMEs in mining and iron industries can increase their sales, reputation and advertising activities, improve their human resources, quality of their products, time management and relationships with their customers and suppliers.

Social media applications consist of social networks, blogs and forums and they are accessible by smartphones and tablets (Wardati \& Mahendrawathi, 2019). Facebook, Twitter (Yap \& Lee, 2014), LinkedIn, Instagram and Pinterest (Wardati \& Mahendrawathi, 2019) are some of the most popular social media platforms and networks that are used by enterprises for their marketing purposes. Moreover, businesses also use some other social media tools for different purposes such as to share audio, photo and video, they use Youtube and Spotify. For collaboration purposes, firms use, Dropbox and Google Docs (Verheyden \& Goeman, 2013). But comparing to other social media networks, the number of Facebook users is higher in the worldwide since there are around 1.69 billion Facebook users (Statista, 2020). According to Statista (2021), the numbers of Facebook users in Slovakia and Hungary were 3.25 and 6.74 millon, respectively in February, 2021 (Statista, 2021). Considering to the number of users on the total populations of these nations, the percentages are quite similar.

However, since the characteristics of businesses such as age and size have been a determinant factor for the decision making process (Yildiz et al., 2013), selection of firm strategies (Cucculelli, 2018), success, innovation (Withers et al., 2011) and marketing performance of firms (Gati \& Bauer, 2019), it might also influence social media usage of enterprises. This is the reason why this paper consider age and size of SMEs and aims to explore whether they are determinant factors in the usage of social media tools by SMEs. In this regard, the research 
question is as follows: Does social media usage by SMEs differ depending on their size and age? In parallel with this target, the research investigates 303 Slovakian and 399 Hungarian SMEs.

Concerning the differences in the usage of social media platforms between businesses depending on their size, financial power, human resources, structure and flexibility of firms have been major arguments for the researchers to consider (Gavurova et al. 2018; Wamba \& Carter, 2013). For instance, since larger firms have more financial sources, they are more likely to improve their competencies than smaller firms (Withers et al., 2011) and more likely to use social networks (Eggers et al., 2017). Having more financial power enables larger firms to have easier access conditions to Information Technology (IT) knowledge that motivate them to apply and use novel technological tools and platforms (Fedorko et al. 2018; Bruque \& Moyano, 2007). Some studies also confirm the fact that larger enterprises own and use social media platforms more than smaller enterprises (Verheyden \& Goeman, 2013; Becker \& Lee, 2019). On the other hand, regarding firm structure, larger firms have more hierarchical levels in their organizations that make them to implement less innovative actions and to be further from their clients and executives comparing to smaller businesses (Wamba \& Carter, 2013). Since smaller firms have less hierarchical organization structure, this characteristic makes smaller firms to be more flexible to seize and implement new technologies and innovative tools comparing to their larger counterparts (Stockdale, et al., 2012; Withers et al., 2011; Cucculelli, 2018). Some studies also bear out the fact that social media usage by smaller firms is higher than their larger rivals (Yellow, 2018; Olanrewaju et al., 2020).

Regarding firm age and usage of social media by SMEs, similar with firm size, firm structure, resources and flexibility also carry high importance. For instance, since younger firms face with less bureaucracy, have less routines, and have less rigid organizational structure, they become more flexible and more likely to use, adapt and implement new innovative tools into their operations comparing to their older rivals (Withers et al., 2011). This flexible structure and flatter hierarchy in organization enable younger firms to have quick decisions and quick actions to gain chances regarding innovation (Rosenbusch et al., 2011). Similarly, Cucculelli (2018) also state the fact that younger firms are more innovative than their older rivals. On the other hand, since older firms are more experienced, their skills to seize and explore innovative opportunities might be more improved over the years (Cucculelli, 2018). This is because older firms might have more informed about the processes and the tasks that enable them to adapt new technologies. In this regard, continuous learning and knowledge acquisition in long term might have key roles to apply new technological tools. Regarding firm resources, younger SMEs face with more obstacles to receive financial resources and they also encounter difficulties related with liability of newness. This is because they usually have lack of relationship with financial institutions, and they are not well informed about market conditions (Withers et al., 2011). These facts might be reasons for the studies that substantiate higher usage of Information and Communication Technologies (ICTs) and social media platforms by older firms in comparison with younger enterprises (Perrigot et al., 2012; Cirera et al., 2016).

Although many studies compare SMEs of Hungary and Slovakia regarding impacts of socio-economic conditions (Oláh et al., 2019; Ivanová \& Cepel, 2018;Virglerova et al., 2020), this study examines SMEs from different perspectives by focusing on their characteristics and their usage of social media platforms. Since these countries have similar socio-economic conditions, analyzing differences in the social media usage of SMEs might be noteworthy to fulfill the gap in the related literature. Moreover, since one of the main focuses of this research is SMEs in mining and iron industries, analyzing social media usage of firm in those sectors will fulfill the gap in academic literature.

The rest of the paper is organized as follows. Material and Methods presents the development of research hypotheses by based on previous empirical studies and also clarifies the methods and approaches that the researchers consider when making their analyses. The findings of this research are illustrated and explained in Results section. Moreover, the researchers propose some policy implications and prospective reasons of the results in Discussion. Lastly, the researchers highlight the key issues of this paper and the limitations of this research in Conclusions.

\section{Material and Method}

\section{Research Objective}

The aim of this paper is to explore and analyse whether length of doing business and size of SMEs are determinant factors for the usage of social media marketing channels by SMEs or not. In parallel with this aim, the researchers have created an online questionnaire survey to collect the research data. The data collection process was performed between September 2019 and March 2020.

\section{Research Sample and Data Collection Process}

The research sample was generated from Cribis database by employing random sampling method. The randomly selected Hungarian and Slovakian SMEs were e-mailed by the research team. The respondents who are managers and owners of SMEs have fulfilled the same questionnaires via the link of online survey that is attached in the emails. The total number of respondents is 702, while 399 of them are owners or managers of Hungarian SMEs and 303 of them are Slovakian owners of managers of SMEs. 


\section{Research Hypotheses}

As already mentioned in Introduction Section, the empirical results of previous studies make the researchers to develop the research hypotheses as follows:

H1: There is a statistically significant difference between the mean volumes of social media usage of larger and smaller SMEs.

H2: There is a statistically significant difference between the mean volumes of social media usage of younger and older SMEs.

$5 \%$ level of significance is chosen by the researchers to support or reject the above-mentioned hypotheses. Thus, $\mathrm{p}$ values that are lower than the 5\% significance level enable the researchers to support alternative hypotheses and reject the null hypotheses that are set as the nonexistence of the significant differences between the mean volumes of social media usage of larger-smaller and younger-older SMEs.

\section{Research Variables}

The researchers have selected four following survey questions from the questionnaire to measure the social media usage by SMEs: "Thanks to social media, our business can respond more flexibly to market developments", "Social media helps our business quickly share information with customers and partners", "Our business has a clear strategy on how to use social media", "Social media supports the growth of our company performance". To scale the responses of the survey participants, the researchers employ Five-point Likert scale as follows: " 1 - strongly disagree, 2 -disagree, 3 - hold no position, 4 -agree, 5 - strongly agree".

Moreover, the researchers have divided both variables that are the characteristics of SMEs namely, length of doing business (firm age) and size into two categories. Firm size is classified as smaller, micro (firms that have 0 to 9 workers, microenterprises) and larger, small and medium-sized firms (the number of staff headcount differs from 10 to 249 for those businesses). Concerning length of doing businesses, the classification of Family Business Institute (2019) is taken into consideration. In this regard, businesses are classified as older if their length of doing business is more than 10 years. On the other hand, businesses that have been operating less than 10 years are categorized as younger SMEs.

\section{Test of Normality}

To find out whether the research sample has normal distribution or not, Skewness, Kurtosis and Levene's Test are considered by the researchers. Tab. 1 that is presented below, illustrates the results of normality test. As indicated in Tab. 1, the volumes from Skewness and Kurtosis tests differ between -1 and +1 , thus, it can be stated the samples for Slovakia and Hungary are normally distributed. Hair et al. (2013) declare that the results from Skewness and Kurtosis that are between -1 to +1 , are indicators of normal distribution.

\section{Tab. 1. Test of Normality}

\begin{tabular}{l|cccccccc}
\hline & \multicolumn{9}{|c}{ Std. } & & \multicolumn{2}{c}{ Levene's Test } \\
\multicolumn{1}{c|}{ Country } & Variance & Mean & Deviation & $95 \%$ CI & Skewness & Kurtosis & Firm Size & Firm Age \\
\hline Slovakia & 0.825 & 2.8804 & 0.90821 & {$[2.77772 .9830]$} & -0.096 & -0.361 & 0.878 & 0.961 \\
\hline Hungary & 0.930 & 3.3051 & 0.96439 & {$[3.21023 .4001]$} & -0.367 & -0.539 & 0.614 & 0.173 \\
\hline
\end{tabular}

Source: own calculations.

Regarding the results of Levene's test, as demonstrated above in Tab. 1, the volumes are higher than 5\% level of significance. For this reason, it can be inferred that there is not any statistical differences between the variances of groups, thus, the varioances are homogenous. Having this result also makes this paper to fulfill another assumption of normality test. In line with these results, the researchers perform one of the parametric tests, namely, Independent Sample T test, and compare the mean volumes of social media usage of largersmaller and older-younger SMEs. To perform these analyses, the researchers run SPSS statistical program.

\section{Sample Profile}

Corresponding sample profile, the researchers explain the details by Tab. 2 that is presented below. Some of the characteristics of SMEs, and the respondents have clearly indicated in this table. For instance, the percentages of microenterprises in the total Slovakian and Hungarian samples are 56.44\% and $67.17 \%$, respectively. Moreover, majority of SMEs in both samples (71.29\% of Slovak SMEs and 63.16\% of Hungarian SMEs) have been operating for more than 10 years. When it comes to the sectors where those businesses operate, $92.74 \%$ of firms in Slovak sample (281 SMEs) operate in mining and iron industries. On the other hand, this percentage for Hungarian sample is $95.99 \%$ (383 SMEs) as illustrated in Tab. 2. Regarding legal structure of companies, most of them work as limited liability companies (72.94\% of Slovakian firms and $60.15 \%$ of Hungarian SMEs). 
Concerning the respondents characteristics such as gender and job status, majority of the respondents in Slovakian an Hungaian SMEs are male and owner of those enterprises. While 208 respondents $(69.65 \%$ of all respondents) in Slovakian sample is male, this volume for Hungarian sample is 275 (68.92\% of all survey participants in Hungary). Regarding job status, $76.9 \%$ of the Slovakian survey participants (233 respondents) are owners of the companies, while this percentage for Slovakian sample 68.17\% (272 Hungarian respondents are owners of SMEs).

Tab. 2. Sample profile

\begin{tabular}{|c|c|c|c|c|c|c|}
\hline & & & \multicolumn{2}{|c|}{ Slovak } & \multicolumn{2}{|r|}{ Hun } \\
\hline & & & $n$ & Share & $n$ & Share \\
\hline \multirow{4}{*}{\multicolumn{2}{|c|}{ Firm size }} & micro & 171 & $56.44 \%$ & 268 & $67.17 \%$ \\
\hline & & small & 90 & $29.70 \%$ & 73 & $18.29 \%$ \\
\hline & & medium & 42 & $13.86 \%$ & 58 & $14.54 \%$ \\
\hline & & Total & 303 & $100 \%$ & 399 & $100 \%$ \\
\hline \multirow{4}{*}{\multicolumn{2}{|c|}{ Firm age }} & up to 5years & 43 & $14.19 \%$ & 85 & $21.30 \%$ \\
\hline & & 6 to 10 years & 44 & $14.52 \%$ & 62 & $15.54 \%$ \\
\hline & & more than 10 years & 216 & $71.29 \%$ & 252 & $63.16 \%$ \\
\hline & & Total & 303 & $100 \%$ & 399 & $100 \%$ \\
\hline \multirow{5}{*}{\multicolumn{2}{|c|}{ Legal Structure }} & sole proprietorship & 50 & $16.50 \%$ & 109 & $27.32 \%$ \\
\hline & & limited liability & 221 & $72.94 \%$ & 240 & $60.15 \%$ \\
\hline & & joint stock company & 16 & $5.28 \%$ & 18 & $4.51 \%$ \\
\hline & & other & 16 & $5.28 \%$ & 32 & $8.02 \%$ \\
\hline & & Total & 303 & $100 \%$ & 399 & $100 \%$ \\
\hline \multirow{3}{*}{\multicolumn{2}{|c|}{ Sector }} & Mining \& iron & 281 & $92.74 \%$ & 383 & $95.99 \%$ \\
\hline & & other & 22 & $7.26 \%$ & 16 & $4.01 \%$ \\
\hline & & Total & 303 & $100 \%$ & 399 & $100 \%$ \\
\hline \multirow{3}{*}{\multicolumn{2}{|c|}{ Respondents' gender }} & female & 95 & $31.35 \%$ & 124 & $31.08 \%$ \\
\hline & & male & 208 & $69.65 \%$ & 275 & $68.92 \%$ \\
\hline & & Total & 303 & $100 \%$ & 399 & $100 \%$ \\
\hline \multirow{3}{*}{\multicolumn{2}{|c|}{ Respondents' job position }} & manager & 70 & $23.10 \%$ & 127 & $31.83 \%$ \\
\hline & & owner & 233 & $76.90 \%$ & 272 & $68.17 \%$ \\
\hline & & Total & 303 & $100 \%$ & 399 & $100 \%$ \\
\hline \multirow{5}{*}{$\begin{array}{l}\text { Respondents' } \\
\text { education } \\
\text { depending on } \\
\text { firm size }\end{array}$} & \multirow{5}{*}{ Small \& medium } & Minimum bachelor's & 130 & $76.02 \%$ & 223 & $83.20 \%$ \\
\hline & & Less educated & 41 & $23.98 \%$ & 45 & $16.80 \%$ \\
\hline & & Minimum bachelor's & 103 & $78.03 \%$ & 109 & $83.20 \%$ \\
\hline & & Less educated & 29 & $21.97 \%$ & 22 & $16.80 \%$ \\
\hline & & & 303 & $100 \%$ & 399 & $100 \%$ \\
\hline \multirow{5}{*}{$\begin{array}{l}\text { Respondents' } \\
\text { age } \\
\text { depending on } \\
\text { firm age }\end{array}$} & Older $\quad$ SMEs & More than 45 years old & 159 & $73.61 \%$ & 162 & $64.29 \%$ \\
\hline & $\begin{array}{l}\text { (more than } 10 \\
\text { years) }\end{array}$ & Up to 45 years old & 57 & $26.39 \%$ & 90 & $35.71 \%$ \\
\hline & Younger SMEs & More than 45years old & 28 & $32.18 \%$ & 103 & $70.06 \%$ \\
\hline & up to 10 years & Up to 45 years old & 59 & $67.82 \%$ & 44 & $29.94 \%$ \\
\hline & Total & & 303 & $100 \%$ & 399 & $100 \%$ \\
\hline
\end{tabular}

Source: own calculations.

\section{Results}

The results of Independent $\mathrm{T}$ test regarding size and social media usage of SMEs are presented below, in Tab. 3. As it is seen in this table, p values (Sig.) for both samples are higher than $5 \%$ level of significance (Slovakia: $\mathrm{t}(301)=0.951, \mathrm{p}=0.342>0.05$; Hungary: $\mathrm{t}(397)=-0.942, \mathrm{p}=0.347>0.05)$. In this regard, this paper proves the fact that there is not statistically significant difference in the usage of social media platforms by smaller and larger SMEs. This result is valid for both Slovakian and Hungarian SMEs. Having this result makes the researchers to fail to support $\mathrm{H} 1$ hypothesis that assumes the existence of differences between the mean volumes of social media usage by smaller and larger SMEs. 


\begin{tabular}{l|cc|cc|ccc}
\hline \multirow{2}{*}{ Country } & \multicolumn{2}{|c|}{$\mathrm{n}$} & \multicolumn{2}{c|}{ Mean } & \multicolumn{3}{|c}{ T test for Equality of Means } \\
& micro & $\begin{array}{c}\text { small \& } \\
\text { medium }\end{array}$ & micro & $\begin{array}{r}\text { small \& } \\
\text { medium }\end{array}$ & $\mathrm{df}$ & $\mathrm{t}$ & $\mathrm{Sig}$. \\
\hline Slovakia & 171 & 132 & 2.9240 & 2.8239 & 301 & 0.951 & 0.342 \\
Hungary & 268 & 131 & 3.2733 & 3.3702 & 397 & -0.942 & 0.347 \\
\hline
\end{tabular}

Source: Own calculations.

Concerning to age (length of doing business) of SMEs and their social media usage, Tab. 4 that is provided below, illustrates the results. According to the table, p values (Sig.) for both samples are lower than 5\% significance level (Slovakia: $\mathrm{t}(301)=-2.589, \mathrm{p}=0.010<0.05$; Hungary: $\mathrm{t}(397)=-2.201, \mathrm{p}=0.028<0.05$ ). For this reason, this paper substantiate the fact that significant differences exist between the mean volumes of social media usage by older and younger SMEs. This fact makes this paper to support $\mathrm{H} 2$ hypothesis.

\begin{tabular}{|c|c|c|c|c|c|c|c|}
\hline \multirow[b]{2}{*}{ Country } & \multicolumn{2}{|c|}{$\mathrm{n}$} & \multicolumn{2}{|c|}{ Mean } & \multicolumn{3}{|c|}{$\mathrm{T}$ test for Equality of Means } \\
\hline & $\begin{array}{l}\text { Firm age } \\
<10 \text { years }\end{array}$ & $>10$ years & $\begin{array}{l}\text { Firm age } \\
<10 \text { years }\end{array}$ & $>10$ years & df & $\mathrm{t}$ & Sig. \\
\hline Slovakia & 87 & 216 & 2.6695 & 2.9653 & 301 & -2.589 & 0.010 \\
\hline Hungary & 147 & 252 & 3.1667 & 3.3859 & 397 & -2.201 & 0.028 \\
\hline
\end{tabular}

Furthermore, as it is indicated in Tab. 4, the mean volumes for older SMEs in both samples, Slovakian SMEs (the mean volumes for older and younger SMEs are 2.9653 and 2.6695, respectively) and Hungarian SMEs (the mean volumes for older and younger SMEs are 3.1667 and 3.3859, respectively) are higher than the mean volumes of younger SMEs. Thus, it can be stated that older Slovakian and older Hungarian SMEs more positively perceive the usage of social media channels in their activities in comparison with their younger counterparts.

\section{Discussion}

Concerning the social media usage by SMEs depending on firm size, as presented in Results section, this paper does not find any significant differences between smaller and larger SMEs. This result makes this paper to have compatible findings with the studies of Wamba and Carter (2013), Žufan, et al. (2020) and Civelek et al. (2020) since these researchers also confirm the nonexistence of the differences between smaller and larger SMEs' social media platforms and networks usage. On the other hand, this result of this paper is not consistent with the studies of Verheyden and Goeman (2013), Becker and Lee (2019) and Olanrewaju et al. (2020) that express the differences between social media usage of smaller and larger enterprises.

Education level of the owners and managers of businesses might be reason for the similarities in the usage of social media platforms by smaller and larger SMEs. This is because a positive relationship exists between education level and usage (Mazzarol, 2015; Deryabina \& Trubnikova, 2020), adaptation (Wamba \& Carter, 2013) of new interned based marketing channels. According to the research data, most of Slovakian and Hungarian executives and owners in micro $(76.02 \%$ of Slovakian respondents and $83.2 \%$ of Hungarian respondents) and small, medium-sized enterprises (78.03\% of Slovakian respondents and $83.2 \%$ of Hungarian respondents) have minimum bachelor's degree. Higher educational status of company executives might have enabled them to perform more innovative actions by applying the usage of internet-based, digital technologies and social media networks. Thus, this fact might be a strong argument to explain similar behaviours of smaller and larger SMEs regarding the usage of social media networks.

Corresponding to social media usage of younger and older SMEs, this paper confirms the differences. According to the results of this paper, older SMEs perform more activities via social media platforms comparing with younger SMEs. In this regard, this paper finds similar results with Perrigot et al. (2012) and Cirera et al. (2016) that also corroborate the higher usage of ICTs and social media platforms by older enterprises than their younger counterparts. But the result of this paper regarding firm age is not compatible with the findings of Withers et al. (2011), Cucculelli (2018), Žufan et al. (2020), and Yildiz et al. (2013) since some of these studies do not confirm the differences in social media usage and innovative performance of SMEs, while others prove the higher usage of social media platforms by younger SMEs comparing with older SMEs.

The reason why older SMEs use social media networks and platforms more than younger SMEs might be related with the experience of owners and executives in older SMEs. This is because experience enables to seize novel technological tools and opportunities (Cucculelli, 2018). Older executives have more experience than their younger counterparts (Ključnikov et al., 2019). In this regard, the percentages of the respondents that are older than 45 years old in older Slovakian and Hungarian SMEs are $73.61 \%$ and $64.29 \%$, respectively. Concerning to the younger SMEs, these percentages are only $32.18 \%$ and $29.94 \%$ for Slovakian and Hungarian samples, 
respectively. Therefore, the experience of older executives in SMEs that have been operating for long years might be reason why older SMEs apply social media channels more than younger SMEs when performing marketing activities of their businesses.

Moreover, since this paper verifies similar results in different countries' SMEs, this fact enables this paper to have compatible facts with Wardati and Mahendrawathi (2019). This is because these researchers also mention the similar effects of social media usage in SMEs of various countries. The reason why SMEs in Slovakia and Hungary have similar social media usage might be explained socio-economic conditions of these nations. According to Oláh et al. (2019), Slovakia and Hungary have similar socio-economic conditions. Those socio-economic conditions have influences on firms' innovative performance (Ivanová \& Cepel, 2018) that is positively associated with the usage of social media networks and platforms (Olanrewaju et al, 2020; Qalati et al., 2020). For instance, the perceptions of SMEs regarding legal risk (Virglerova et al., 2020) and market risk, (Dvorsky et al., 2018) are quite similar in these countries. Moreover, Transparency International Corruption Perception Index (2020) show that the scores of Slovakia and Hungary are 49 and 44, respectively. According to the Global Competitiveness Index of the World Bank (2017), the volumes of Slovakia and Hungary from this index are 59 and 60, respectively. Concerning the social media usage, the percentage of social media users in total populations of both nations are also similar. For instance, according to Worldometers (2020), the total population of Hungary is around 9.65 million, while this volume for Slovakia is around 5.46 million and the numbers of Instagram users in Slovakia and Hungary were 1.44 and 2.61 million, respectively in February, 2021 (Statista, 2021). Therefore, the percentages of Instagram users in the total populations of Slovakia and Hungary are $26.4 \%$ and $27.05 \%$, respectively. All these statistics and volumes indicate how socio-economic conditions in these countries are similar. This fact might be a strong argument to explain why this paper finds similar social media usage patterns in both countries' SMEs.

Although this paper finds compatible or opposing results with above mentioned studies regarding age and size and social media usage of SMEs, there are lack of studies that focus on firm size, length of doing business and the social media usage of SMEs in mining and iron industries. For instance, Civelek et al. (2020) analyse the technology enabled marketing usage, size and age of SMEs operating in mining and iron industries of Slovakia, Czechia and Hungary, but the researchers pay regard to those variables' effects on bankruptcy issues of firms. Since the main focus of this paper is analysing the usage of social media usage depending on size and age of SMEs in mining and iron industries, this is an originality of this research. Thus, this fact makes this paper to be sole in this specific topic and to fulfil the research gap.

Concerning implications for the social media usage and recommendations for the management of firms in mining and iron industries, SMEs in those sectors can be more active to find opportunities and implement online and digital technologies into their organizations regarding their marketing operations. Except that, since social media enables businesses to widen their networks, they can also be more active via these channels to have more contacts with their prospective and existing suppliers, partners and customers. When communicating with the above-mentioned players that are surrounded in their external environment, SMEs in mining and iron industries also need to know and determine efficient communication, promotion and marketing strategies. In this regard, the roles of top management team and firm executives in decision making process carry high importance. Since the personal characteristics of owners, shareholders, entrepreneurs and managers might influence firms' decisions on the usage and adaptation of social media platforms, the awareness and competencies of these executives regarding the usage of these channels need to be improved. Therefore, some educations and trainings might be provided to develop entrepreneurial, innovative and creative postures of the executives of firms operating in mining and iron industries. These trainings and courses can also make company executives to improve their skills regarding the usage and adaptation of technology based, digital marketing technologies. To achieve these targets, universities, policy makers and SMEs can work together and create effective strategies for SMEs to make them more competitive against their larger rivals. Furthermore, online trade fairs that enable firms in mining and iron industries to share their products or services, might stimulate the usage of online platforms by those businesses too. Mining firms face with political and reputational risks because of political uncertainties and regulations of policy makers. To overcome those problems, firms in mining industry might apply some Corporate Social Responsibility (CSR) projects (Fahmi \& Zulbainarni, 2021) and they can post those projects via their social media platforms to have a good reputation from the perspective of their customers and suppliers and policy makers.

\section{Conclusions}

Although SMEs operating in mining and iron industries provide considerable benefits for world economy, they encounter more impediments than their larger counterparts when receiving funding and making investments for their marketing activities. Since digital and online marketing tools including social media platforms enable SMEs to find less costly solutions in marketing, the usage of these channels by SMEs is of great value. But even SMEs might use social media platforms, the characteristics of these enterprises might affect their preferences 
when adapting these channels. In this regard, the aim of this research to analyse and find out the differences in the usage of social media platforms by SMEs depending on their size and length of doing business. Since this paper analyses the usage of social media channels by SMEs that are in iron and mining industries and from different countries, this research might make value addition to the related literature.

The data that this paper investigates is collected by a questionnaire survey. The researchers have applied random sampling method to select the respondents from Cribis database. After that, the researchers have sent the link of the online questionnaires to the randomly selected respondents. 303 owners or managers of Slovakian SMEs, and 399 owners or managers of Hungarian SMEs have fulfilled the survey. The researchers perform Independent Sample T test via SPSS statistical software to compare the usage of social media channels by smaller-larger and younger-older SMEs.

The results of this paper confirm that firm size is not a determinant factor that might influence the usage of these tools by SMEs. Education level of the firm executives might be a strong argument to support the nonexistence of the differences between the smaller and larger SMEs' social media usage. On the other hand, length of doing business determines the usage of social media channels by SMEs and older SMEs adapt and use social media channels in their marketing activities more than their younger counterparts. The reason of the differences between older and younger SMEs might stem from the experience of executives in older SMEs.

Moreover, above mentioned results have been confirmed in both samples, Slovak and Hungarian. The reason why both samples show similar social media usage patterns of SMEs might be explained by the similar socio-economic factors in these nations. Since these nations have similar rankings and volumes from the Corruption Perception and Global Competitiveness indexes and have similar percentages regarding the number of users of most popular social media platforms in the total population, these indicators might be strong arguments to support the same usage patterns in various countries.

Eagerness of SMEs in iron and mining industries to implement the social media platforms in their marketing activities and their willingness for widening their networks stimulate their adoption of these marketing channels into their operations. Except that, the abilities of SMEs to apply effective communication, promotion and branding strategies for their digital marketing activities are highly beneficial for them to have better sales and income volumes. On the other hand, personal characteristics and competencies of company executives in the usage of these platforms, should not be ignored. Since these characteristics and abilities might shape and determine firms' marketing strategies, some trainings and courses that are related with effective usage of social media channels might be created for prospective and existing executives. In this regard, the collaboration of universities, policy makers and SMEs can create synergy for the development of creative and innovative ideas for the usage of social media platforms by mining and iron firms. Moreover, the participation and the existence of SMEs operating in mining and iron sectors to online trade fairs and CSR projects might be beneficial for their reputation. Those facts might create opportunities for firms in iron and mining industries to compete with their larger rivals in those sectors.

Although this research provides significant findings regarding social media usage by SMEs that operate in iron and mining industry of various nations, it is limited in some extents. For instance, social media usage of SMEs is evaluated depending on the perceptions of firm executives. Thus, this paper does not employ an external objective measurement to evaluate social media usage of SMEs. Moreover, since this research collects the data by an online questionnaire the eagerness of respondents might be limitation too. But the research team have given a great effort to cope with this issue. The researchers can consider these problems when making new studies. Moreover, they can include larger sized enterprises, businesses from other countries and other firmindividual level characteristics into their analyses to compare the differences between companies' digital and online marketing activities.

\section{References}

Becker, K., \& Lee, J. W. (2019). Organizational usage of social media for corporate reputation management. The Journal of Asian Finance, Economics and Business, 6(1), 231-240. https://doi.org/10.13106/JAFEB.2019.VOL6.NO1.231

Bruque, S., \& Moyano, J. (2007). Organisational determinants of information technology adoption and implementation in SMEs: The case of family and cooperative firms. Technovation, 27(5), 241-253. https://doi.org/10.1016/j.technovation.2006.12.003

Cirera, X., Lage, F. \& Sabetti, L. (2016). ICT use, innovation, and productivity evidence from Sub-Saharan Africa. World Bank Policy Research Working Paper 7868. Trade and Competitiveness Global Practice Group.

Civelek, M., Gajdka, K., Světlík, J., \& Vavrečka, V. (2020). Differences in the usage of online marketing and social media tools: evidence from Czech, Slovakian and Hungarian SMEs.Equilibrium. Quarterly Journal of Economics and Economic Policy, 15(3), 537-563. https://doi.org/10.24136/eq.2020.024 
Civelek, M., Ključnikov, A., Vavrečka, V. \& Gajdka, K. (2020). The Usage of Technology-Enabled Marketing Tools by SMEs and Their Bankruptcy Concerns: Evidence from Visegrad Countries. Acta Montanistica Slovaca, 25 (3), 263-273.

Cucculelli, M. (2008). Firm age and the probability of product innovation. Do CEO tenure and product tenure matter?. J Evol Econ 28, 153-179. https://doi.org/10.1007/s00191-017-0542-4

Deryabina G., \& Trubnikova N. (2020). Digital B2B communications: economic and marketing effects. In: Popkova E., Sergi B. (eds) Digital Economy: Complexity and Variety vs. Rationality. ISC 2019. Lecture Notes in Networks and Systems, 87. Springer, Cham. https://doi.org/10.1007/978-3-030-29586-8_98

Dvorsky, J., Popp, J., Virglerova, Z., Kovács, S., \& Oláh, J. (2018). Assessing the importance of market risk and its sources in SMEs of the visegrad group and Serbia. Advances in Decision Sciences, 22, 1-25. Retrieved from http://ezproxy.techlib.cz/login?url=https://www.proquest.com/scholarly-journals/assessingimportance-market-risk-sources-smes/docview/2246693155/se-2?accountid=119841

Eggers, F., Hatak, I., Kraus, S. \& Niemand, T. (2017). Technologies that support marketing and market development in SMEs-Evidence from social networks. Journal of Small Business Management, 55(2), 270-302. https://doi.org/10.1111/jsbm.12313

European Commission (2003). Recommendation of 6 May 2003 concerning the definition of micro, small and medium-sized enterprises (Text with EEA relevance) (notified under document number C(2003) 1422). Retrieved from https://eur-lex.europa.eu/legal-content/EN/TXT/?uri=CELEX:32003H0361.

Fahmi, D. Y., \& Zulbainarni, N. (2021). Mining social media (twitter) data for corporate image analysis: a case study in the indonesian mining industry. In Journal of Physics: Conference Series, 1811(1), IOP Publishing.

Family Business Institute (2019). Definition of Young Firm. Retrieved from https://www.familybusinessinstitute.com/.

Fedorko, I., Bacik, R., \& Gavurova, B. (2018). Technology acceptance model in e-commerce segment. Management \& Marketing-Challenges for the Knowledge Society, 13(4), 1242-1256. doi: 10.2478/mmcks-2018-0034

Freixanet, J., Braojos, J., Rialp-Criado, A., \& Rialp-Criado, J. (2020). Does international entrepreneurial orientation foster innovation performance? The mediating role of social media and open innovation. The International Journal of Entrepreneurship and Innovation, 22(1), 33-44. https://doi.org/10.1177/1465750320922320

Gavurova, B., Bacik, R., Fedorko, R., \& Nastisin, L. (2018). The customer's brand experience in the light of selected performance indicators in the social media environment. Journal of Competitiveness, 10(2), 7284. https://doi.org/10.7441/joc.2018.02.05

Global Competitiveness Index of the World Bank (2017), Retrieved from https://tcdata360. worldbank.org/indicators/gci?country=SVK\&indicator=632\&countries=HUN\&viz=line _chart\&years=2007,2017\#table-link

Guha, S., Harrigan, P., \& Soutar, G. (2018). Linking social media to customer relationship management (CRM): A qualitative study on SMEs. Journal of Small Business \& Entrepreneurship, 30(3), 193-214. https://doi.org/10.1080/08276331.2017.1399628

Hair, J. F., Black, W. C., Babin, B. J., Anderson, R. E., \& Tatham, R. L. (2013). Multivariate data analysis. Upper Saddle River: Pearson Education Limited.

Hitchen, E. L., Nylund, P. A., Ferràs, X. \& Mussons, S. (2017). Social media: open innovation in SMEs finds new support. Journal of Business Strategy, 38(3), 21-29. https://doi.org/10.1108/JBS-02-2016-0015

Ivanová, E., \& Čepel, M. (2018). The impact of innovation performance on the competitiveness of the Visegrad 4 countries. Journal of Competitiveness, 10(1), 54. https://doi.org/10.7441/joc.2018.01.04

Jokonya, O., \& Mugisha, C. (2019). Factors influencing retail SMEs adoption of social media for digital marketing. In ECSM 2019 6th European Conference on Social Media (p. 145). Academic Conferences and publishing limited.

Ključnikov, A., Mehmet Civelek, Petr Čech, \& Jitka Kloudová,. (2019). Entrepreneurial orientation of SMEs' executives in the comparative perspective for Czechia and Turkey. Oeconomia Copernicana, 10(4), 773795. https://doi.org/10.24136/oc.2019.035

Mazzarol, T. (2015). SMEs engagement with e-commerce, e-business and e-marketing. Small Enterprise Research, 22(1), 79-90. https://doi.org/10.1080/13215906.2015.1018400

Mount, M., \& Martinez, M. G. (2014). Social Media: A tool for open innovation. California Management Review, 56(4), 124-143. https://doi.org/10.1525/cmr.2014.56.4.124

Olanrewaju, A. S. T., Hossain, M. A., Whiteside, N. \& Mercieca, P. (2020). Social media and entrepreneurship research: A literature review. International Journal of Information Management, 50 (2020), 90-110. https://doi.org/10.1016/j.ijinfomgt.2019.05.011 
Oláh J, Virglerova Z, Popp J, Kliestikova J, \& Kovács S. (2019). The Assessment of Non-Financial Risk Sources of SMES in the V4 Countries and Serbia. Sustainability. 11(17). https://doi.org/10.3390/su11174806

Perrigot, R., Kacker, M., Basset, G., \& Cliquet, G. (2012). Antecedents of early adoption and use of social media networks for stakeholder communications: Evidence from franchising. Journal of Small Business Management, 50(4), 539-565. https://doi.org/10.1111/j.1540-627X.2012.00366.X

Qalati, S. A., Wenyuan, L. I., Vela, E. G., Ali, B. U. X., Barbosa, B., \& Herzallah, A. M. (2020). Effects of technological, organizational, and environmental factors on social media adoption. The Journal of Asian $\begin{array}{llll}\text { Finance, } \quad \text { Economics } & \text { Bnd }\end{array}$ https://doi.org/10.13106/jafeb.2020.vol7.no10.989

Quinton, S., \& Wilson, D. (2016). Tensions and ties in social media networks: Towards a model of understanding business relationship development and business performance enhancement through the use of LinkedIn. Industrial Marketing Management, https://doi.org/10.1016/j.indmarman.2015.12.001

Rosenbusch, N., Brinckmann, J., \& Bausch, A., (2011). Is innovation always beneficial? A meta-analysis of the relationship between innovation and performance in SMEs. Journal of Business Venturing, 26, 41-457. https://doi.org/10.1016/j.jbusvent.2009.12.002

Shaltoni, A.M. (2017). From websites to social media: exploring the adoption of internet marketing in emerging industrial markets. Journal of Business \& Industrial Marketing, 32(7), 1009-1019. https://doi.org/10.1108/JBIM-06-2016-0122

Statista, (2020). Number of worldwide Facebook users. Retrieved from https://www.statista.com/statistics/490424/number-of-worldwide-facebook-users/

Statista, (2021). Instagram Users in Hungary and Slovakia. Retrieved from https://www.statista.com/statistics/1024797/instagram-users-hungary/ https://www.statista.com/statistics/1024807/instagram-users-slovakia/

Stockdale, R., Ahmed, A., \& Scheepers, H. (2012). Identifying Business Value From The Use Of Social Media: An Sme Perspective. PACIS 2012 Proceedings. Paper 169. Retreived from http://aisel.aisnet.org/pacis2012/169

Transparency International Corruption Perception Index, (2020). Retrieved from https://www.transparency.org/en/cpi/2020/index/hun\#

Verheyden, M., \& Goeman, K. (2013). Does (company) size matter? differences in social media usage for business purposes. Journal of Applied Quantitative Methods, 8(4). Retrieved from http://jaqm.ro/issues/volume-8,issue-4/pdfs/1_VERHEYDEN_GOEMAN.pdf

Virglerova, Z., Conte, F., Amoah, J., \& Massaro, M. R. (2020). The perception of legal risk and its impact on the business of SMEs. International Journal of Entrepreneurial Knowledge, 8(2), 1-13. https://doi.org/10.37335/ijek.v8i2.115

Wamba , S. F. \& Carter, L. (2013). Twitter adoption and use by SMEs: An Empirical Study, 46th Hawaii International Conference on System Sciences, Wailea, HI, USA, 2042-2049, https://doi.org/10.1109/HICSS.2013.577

Wardati, N. K., \& Mahendrawathi, E. R. (2019). The impact of social media usage on the sales process in small and medium enterprises (SMEs): A systematic literature review. Procedia Computer Science, 161, 976983. https://doi.org/10.1016/j.procs.2019.11.207

Withers, M. C., Drnevich, P. L. \& Marino, L. (2011). Doing More with Less: The disordinal implications of firm age for leveraging capabilities for innovation activity, Journal of Small Business Management, 49(4), 515-536, https://doi.org/10.1111/j.1540-627X.2011.00334.x

Worldometers, (2020). Population of Hungary and Slovakia. Retrieved from Population, https://www.worldometers.info/world-population/slovakia-population/

Yap, S. F. C., \& Lee, C. K. C. (2014). Leveraging the power of online social networks: a contingency approach. Marketing Intelligence \& Planning, 32(3), 345-374. https://doi.org/10.1108/MIP-03-2013-0048

Yellow (2018). Yellow social media report 2018. Part two-Businesses Retrieved from Australia. Retrieved from https://www.yellow.com.au/wp-content/uploads/2018/06/Yellow-Social-Media-Report-2018Businesses.pdf

Yildiz, O., Çetinkaya, Ö., Bozkurt, A. K. \& Ayci, A. (2013). The relationships between technological investment, firm size, firm age and the growth rate of innovational performance, Procedia - Social and Behavioral Sciences, 99, 590-599. https://doi.org/10.1016/j.sbspro.2013.10.529

Žufan, J., Civelek, M., Hamarneh, I., Kmeco, L. (2020). The impacts of firm characteristics on social media usage of SMEs: Evidence from the Czech Republic. International Journal of Entrepreneurial Knowledge, 8(1), 102-113. https://doi.org/10.37335/ijek.v8i1.111 